\title{
EMPIRICAL EXAMINATION OF THE IMPLEMENTATION OF ELECTRONIC PAYMENT SYSTEMS IN SERVICE DELIVERY OF INSURANCE COMPANIES IN NIGERIA
}

\author{
Samson Ifejionu Nwankwo', Sunday Stephen Ajemunigbohun", Ayodele Samuel Iyun"I \\ 1,2 Lagos State University, Lagos, Nigeria \\ ${ }^{3}$ Custodian and Allied Insurance Company Limited, Lagos, Nigeria
}

\section{ABSTRACT}

This study was designed with the aim to investigate the implementation of electronic payment systems in the service delivery of various insurance companies operating in Nigeria. To this end, the researchers have been able to assess if electronic payment systems have improved service delivery of insurance companies in Nigeria, and thus ascertained its acceptance level within the Nigeria's insurance business environment. The study employed a cross-sectional type of survey design. The study commenced with the gathering of relevant literature. More so, a simple random technique was employed and relevant data were gathered through the use of structured questionnaire. The sample population consisted of 79 respondents made up of some members of staff drawn from 32 insurance companies which were selected from the directory of member companies. The major statistical technique employed for this study was a KolmogorovSmirnov test. Two hypotheses were tested in this study. The hypotheses tested in the study found that electronic payment systems have improved service delivery of insurance companies in Nigeria but yet to be fully accepted within the Nigeria's insurance market space. The study confirms the significant influence of electronic payment system in the service delivery of insurance companies Nigeria. The study recommends that continuous investment in technology is imperatively crucial to allow for cordial business relationship among all players in the Nigerian insurance market environment. Also, greater attention should be placed on customers' education and engagement in the use of electronic payment systems to enhance business transactions, and Government initiative towards cashless policy should be made feasible by continuously encouraging members of the public towards transacting business electronically.

\section{JEL CLASSIFICATION \& KEYWORDS}

- U10 ELECTRONIC PAYMENT - SERVICE DELIVERY - IMPLEMENTATION @ INSURANCE COMPANIES $\square$ NIGERIA

\section{INTRODUCTION}

Technology readiness to backing payment system in the Nigerian insurance market is, indeed, a herculean task due to its peculiar nature which is further encapsulated by the vagaries of Nigeria's business and market forces. The recent study of Asikhia (2010) had opined that until companies are able to deliver their services in an efficient manner, with technology as key determinant, financial institutions may not be able to retain their customers. The decisions concerning where, when and how to deliver such service have a significant role on the nature of customers' service experiences (Lovelock \& Wright, 1999).

늑 samsonnwankwo2007@yahoo.com

UI I insurancelecturerlasu2009@yahoo.com

III ayodeleiyun@yahoo.com

www.journals.cz
However, technology is being employed to capture information on customers, which in turn is used to monitor the customers' buying behaviour and thus communicate with them via personalized offers (Egan, 2004). Oghojafor, Aduloju, \& Olowokudejo (2011) had emphasized that, in the world of business, electronic commerce serves as the cornerstone which evolves relationship within strategicoriented business environment and thus, strategized for modern competitive edge. The work of Idris, Olumoko, \& Ajemunigbohun (2013) opined that enormous effort should be put together at integrating information technology, customer service and firm performance; and thus stipulated that technology is to the advantage of customer and should lead to customer loyalty, as organization can communicate with customers using up-to-date techniques on a real basis which will remove uncertainty and lead to the creation of trust.

Electronic payment system is being noted as vital part of e-commerce. Imperatively, the wider patronage of e-commerce is being said to hinge upon the availability of a guaranteed and trusted e-payment system (Sumanjeet, 2009; Baddeley, 2004). Some previous studies (such as Oladele \& Akanbi, 2012; Ayo \& Ukpere, 2010; Zulu, 2006)had noted problems militating against e-payment to include: integrity, non-reputation, confidentiality, reliability, authentication, authorization, connectivity failure in telephone lines, devoid of proper legal and regulatory framework, and low level of credit access.

While much studies are yet to be recorded on electronic payment implementation in the service delivery of insurance companies in Nigeria; some notable studies, many of which are recent, seem to suggest that, apart from differences in the methodology and variables adopted, electronic payments systems implementation had been feasible in the customer service delivery in the banking sector of the financial system (Moses-Ashike, 2012; Auta, 2010; Fenuga \& Oladejo, 2010). For example, the study of Kaleem and Ahmad (2008) noted that increased availability and accessibility of more self-service distribution channels assists bank administration in reducing the expensive branch network and its associate staff overheads. Some other earlier studies (such as Howcroft, Hamilton, \& Hewer, 2002; Kiang, Raghu, \& Hueu-Min, 2000) established that the most important factors encouraging consumers to use electronic banking and lower fees followed by reducing paper work and human error, which invariably curtail disputes. More so, a decrease in the proportion of customers visiting banks with an increase in alternative channels of distribution had been said to reduce the queues in the branches (Thornton \& White, 2001).

This article, therefore, attempts to provide answers to the following research questions: Has there been improvement in the implementation of electronic payment systems in the service delivery of insurance companies in Nigeria? or Has electronic payment system been fully accepted in the 
Nigerian insurance market environment? The remainder of the paper is organized as follows: the review of existing literature on electronic payment in relation to service delivery including the theoretical underpins. The methodology section takes note of the empirical analysis including the sample and data collection procedure, the measurement of the variables of interest, and the results. The concluding part presents the discussion of research findings, recommendations, contribution to knowledge, and suggestion for further studies.

\section{Literature Review}

Electronic payment is being described as the automatic processes of exchanging pecuniary value among parties in business related transactions and transmitting such value via the information technology network (Ayo \& Ukpere, 2010). Stan (1997) sees it as a system of payment whereby transactions take place electronically without the use of physical cash. Steve (1996) as cited in Fenuga (2010) defined electronic payment as a system that is automated via the use of information technology where bank transactions are done within and without banking hall. Olive (2007) as cited in Tennyson and Mercy (2014) defined electronic payment is a form of financial transaction in which funds are transferred through an exchange of electronic signals between financial institutions, rather than an exchange of cash, cheque or other negotiable instruments. Otiso (2012) added that the major driving motivation for implementing electronic payment system is towards the enhancement for transaction effectiveness. The commonly used electronic payment channels include automated teller machines (ATM), mobiles phones, point of sales (POS) terminals, online web portals, the payment cards (debit or credit), automated clearing house $(\mathrm{ACH})$, and direct debit/deposits (USAID, 2012; Nnaka, 2009; OECD, 2006; Lee, Yu, \&Kuo, n.d.; Ekwueme, Egbunike, \& Amara, n.d.).

Electronic payment is advantageous in that it is characterized with lower fees coupled with the reduced paper work and human error, which in turn reduces disputes in transactions (Hawcroft et al., 2002). According to studies such as Tennyson \& Mercy (2014), Chandio (2011), and Sumanjeet (2009), the major attributable nature of electronic payment is said to include: security, cost effectiveness, usability, universality, speed, convenience, acceptability and privacy. However, a great deal of benefits had been associated with the use of electronic payment systems such as: easy tackling of payment improves the quality of financial report; promotes economic growth and development; prevents forgery and illegal copying of e-cash; reduces corruption; reduces costs; greater convenience and security; promotes transparency and accountability; portable; efficient and effective (Tennyson \& Mercy, 2014; Agboola, 2006; Davis, 2003; Humphrey, Kim,\& Vale, 2001).

However, the effectiveness of electronic payment systems have been associated with some risk elements. These risk elements had been noted to include: lack of trust, complexity, lack of security, disruption, in information access, lack of specific regulations, cost ineffectiveness, lack of marketing initiatives (Tahir \& Abass, 2013; Lim, Lee \& Kurning, 2007; OECD, 2006; Taylor, Celuch, \& Goodwin 2002). The mentioned risk elements had been ascribed different descriptions by earlier studies; according to Hewer \& Howcroft (1999), the term trust was depicted as a measure of risk. While Suganthi \& Balachandran (2001) viewed security as a risk element, Min \& Gallen (1999) found that the description of information access is a risk element in relation to unwillingness to use Internet channels for commerce. Tennyson \&Mercy (2014) noted further factors that may limit the effectiveness of electronic payment systems to include: inadequate operational facilities, epileptic power supply, frauds, ineffective telecommunication services, access to ICT facilities, high financial risk and insecurity.

A service, according to Kotler \& Armstrong (2008) as cited in Nwankwo \& Durowoju (2011), is being depicted as an activity or benefit that one party can offer to another that is imperatively intangible and does not culminate in the ownership of anything with its production not tied to a physical product. An earlier study of Lovelock \& Wright (1999) see a service as an act or performance that creates benefits for customers by bringing about a desired change in or on behalf of the recipient. However, the quality of the service delivery of an insurance company can be pivoted on marketing hence the intangibility of its service nature; and the unique nature of insurance service is that it is purchased at the present time only for the value to be realized in the future (Ajemunigbohun, Dansu, \& Asokere, 2010). Ikupolati (2008) opined that insurance service is characterized by intangibility, inseparability, variability and ownership of a thing of title that can be transferability.

An earlier study by Toran (1993) had argued that quality should form a significant measure of insurance service. Walker \& Baker (2000) are of the opinion that customer's expectation forms the basis for insurance quality measurement. To this end, Nwankwo \& Ajemunigbohun (2013) had opined that insurance companies should clarify their value and expectations in dealing with prospective and existing customers, as well as putting effort together towards customers' attraction and retention. Importantly, insurance quality measurement, according to an earlier study by King (1992), had been adduced to include: financial stability of the company, insurer's reputation, integrity of agent(s) and the quality of information and guidance from the agent.

\section{Research method}

For the purpose of this study, a cross-sectional survey design was employed. The choice of this survey technique was adopted due to the fact that it observed what happened to sample subjects or variables without any attempt to manipulate or control them (Asika, 2008). More so, survey design was useful due to its ability to predict behaviour and assist researchers in collecting identical information concerning all the cases in a sample (Aldridge \& Levine, 2001). The survey research was aided with the involvement of structured questionnaire in gathering relevant data for this study. However, the respondents' views with respect to the studied variables were coded to improve the completion of the questionnaire which was drawn with the support of Likert-type scaling measurement of 'Agree', 'Indifferent', and 'Not agree'.

The population for this study made up of members of staff within the Nigeria's insurance companies operating in Nigeria. The choice of member company was based on their rank in order of gross premium and market share capabilities (that is, top 32 member companies as documented by the Nigerian Insurer Association, 2013). The sample population was drawn from Lagos state, being the commercial city of Nigeria and platform for a large number of insurance companies to operate. A total of 96 copies of the questionnaires were sent ( 3 copies were sent to each insurance company with a covering letter). To ensure the correctness of responses, frequent telephone calls backed up with few visits were options in a bid for clarity purposes and to encourage filling, handling and returning of the 
distributed questionnaire. To this end, 84 copies of the questionnaire were retrieved while 79 copies were correctly completed and useful for the final analysis (that is, a $83 \%$ effective response rate).

In a bid to achieve the purpose for which the questionnaire was set out, a pilot study was conducted to test the reliability measures. The Cronbach alpha was 0.781 ; which thus indicted that the alpha level was above the standard 0.70 This study took note of both the construct and theoretical validity. The theoretical validity was designed through measures of the variables understudied from well-taught out literatures in relevant studies. The construct validity was designed by giving a set of questionnaire to few selected insurance companies' top managers, IT managers and some members of the academia. These experts went through the instrument and gave their remarks which assisted the researchers to present the instrument in understanding and acceptable manner to the various respondents.

Test of Hypotheses

The researchers established two (2) hypotheses that provide a clear-cut way for the conduct of this research. The hypotheses testing method employed was KolmogorovSmirnov test. The Kolmogorov-Smirnov test is suitable due to fact that it is non-parametric tool used to test the goodness of fit of an ordinal data and calls for a comparison of an observed sample distribution with a theoretical distribution (Cooper \& Schindler, 2005). The test focuses on the largest value of the deviation among observed and theoretical proportions. The Kolmogorov-Smirnov is given as:

$$
D=\max \left|F_{o}(X)-S_{n}(X)\right|
$$

Where $F_{0}(X)=$ the specific cumulative frequency distribution under $\mathrm{H}_{0}$ for any value of $\mathrm{X}$ and is the proportion of cases expected to have scores equal to or less than $X . S_{n}(X)=$ the observed cumulative frequency distribution of a random sample of $\mathrm{N}$ observations where $\mathrm{X}$ is any possible score. The $\mathrm{H}_{\mathrm{o}}$ is the specification of the null hypothesis. The null hypothesis is such that is set up as a logical counterpart of the alternative hypothesis such that if the null hypothesis is untrue, the alternative hypothesis must be true (Pagano, 1994). The procedural steps to testing the hypotheses were as follows: specify the null hypothesis; specify the level of significance; and stipulate the decision rule. The degree of freedom is measured at $5 \%$ level of significance. The decision rule is such that null hypothesis $\left(\mathrm{H}_{0}\right)$ will be rejected once the calculated $D$ (.i.e. $D_{\text {cal }}$ ) is greater than the tabulated $D$ (.i.e. $D_{\text {tab }}$ ) under the divergence level of 0.05 . The tabulated $D$ from the Kolmogorov-Smirnov test table is always represented by (a $(\sqrt{ } \mathrm{N}$ ); where $\alpha=1.36$ and $N=$ number of observation. The critical value of $D$ for sample size of $\mathrm{N}$ must be greater than thirty-five (.i.e. $\mathrm{N}>35$ - for large samples).

1. $\mathrm{H}_{0}$ : Electronic payment systems have not improved service delivery of insurance companies in Nigeria

2. $\mathrm{H}_{0}$ : Electronic payment systems have not been fully accepted in the Nigerian insurance industry

\begin{tabular}{|l|l|l|}
\hline Table 1: Responses to the testing of Hypothesis 1 \\
\hline Alternatives & Responses & Percentage (\%) \\
\hline Agree & 9 & 11.4 \\
\hline Indifferent & 16 & 20.25 \\
\hline Not Agree & 54 & 68.35 \\
\hline Total & 79 & 100 \\
\hline Source: Authors & \\
\hline
\end{tabular}

www.journals.cz

\section{Results and Discussion}

Table 2: Kolmogorov-Smirnov Frequency Table for Hypothesis 1

\begin{tabular}{|l|l|l|l|}
\hline \multicolumn{1}{|c|}{ Hypothesis } & Agree & Indifferent & $\begin{array}{c}\text { Not } \\
\text { agree }\end{array}$ \\
\hline $\begin{array}{l}\text { F = Electronic payment systems have not improved } \\
\text { Service delivery of insurance companies in Nigeria }\end{array}$ & 9 & 16 & 54 \\
\hline $\begin{array}{l}F_{0}(\mathrm{X})=\text { Theoretical cumulative distribution of choice } \\
\text { Under } \mathrm{H}_{0}\end{array}$ & 0.3333 & 0.6666 & 1 \\
\hline $\mathrm{S}_{\mathrm{n}}(\mathrm{X})=$ Cumulative distribution of observed choices & 0.1139 & 0.3164 & 1 \\
\hline $\mathrm{F}_{\mathrm{o}}(\mathrm{X})$ - $\mathrm{S}_{\mathrm{n}}(\mathrm{X}) \mid$ & 0.2194 & 0.3502 & 0 \\
\hline Source: Authors & \multicolumn{5}{|l}{} \\
\hline
\end{tabular}

Hypothesis 1

Electronic payment systems have not improved service delivery of insurance companies in Nigeria. From the above table, it shows that the calculated $D$ value is the point of greatest divergence between the cumulative theoretical distributions and cumulative observed which was determined to be 0.3502 . The tabulated $D$ from the Kolmogorov-Smirnov test table at $(\alpha / \sqrt{ } N=1.36 / \sqrt{ } 79)$ is given as

$$
D=\alpha / \sqrt{ } N=1.36 / \sqrt{ } 79=0.1530
$$

In this instance, hence the calculated $D$ value $(0.3502)$ exceeds the critical value of 0.1530 , the null hypothesis $\left(\mathrm{H}_{0}\right)$ stating that electronic payment systems have not improved service delivery of insurance companies in Nigeria is rejected at $\alpha=0.05$ (see table 2), this, then, indicates that electronic payment systems have improved service delivery of insurance companies in Nigeria, with respect to the responses of the respondents.

\begin{tabular}{|l|l|l|}
\hline Table 3: Responses to the testing of Hypothesis 2 \\
\hline Alternatives & Responses & Percentage (\%) \\
\hline Agree & 47 & 59.5 \\
\hline Indifferent & 21 & 26.58 \\
\hline Not Agree & 11 & 13.92 \\
\hline Total & 79 & 100 \\
\hline Source: Authors & \multicolumn{2}{|l}{} \\
\hline
\end{tabular}

Source: Authors

\begin{tabular}{|l|l|l|l|}
\hline \multicolumn{1}{|c|}{ Table 4: Kolmogorov-Smirnov Frequency } & \multicolumn{3}{|c|}{ Table for Hypothesis 2 } \\
\hline \multicolumn{1}{|c|}{} & Agree & Indifferent & $\begin{array}{c}\text { Not } \\
\text { agree }\end{array}$ \\
\hline $\begin{array}{l}\text { F = Electronic payment systems have not improved } \\
\text { Service delivery of insurance companies in Nigeria }\end{array}$ & 47 & 21 & 11 \\
\hline $\begin{array}{l}F_{0}(X)=\text { Theoretical cumulative distribution of choice } \\
\text { Under } \mathrm{H}_{\circ}\end{array}$ & 0.3333 & 0.6666 & 1 \\
\hline $\mathrm{S}_{\mathrm{n}}(\mathrm{X})=$ Cumulative distribution of observed choices & 0.5949 & 0.8607 & 1 \\
\hline $\mathrm{F}_{\mathrm{o}}(\mathrm{X})$ - $\mathrm{S}_{\mathrm{n}}(\mathrm{X}) \mid$ & -0.2616 & -0.1941 & 0 \\
\hline Source: Authors & \multicolumn{4}{|l}{} \\
\hline
\end{tabular}

\section{Hypothesis 2}

Electronic payment systems have not been fully accepted in the Nigerian insurance industry. From the above table, it shows that the calculated $D$ value is the point of greatest divergence between the cumulative theoretical distributions and cumulative observed which was determined to be -0.2616 . The tabulated $D$ from the Kolmogorov-Smirnov test table at $(\alpha / \sqrt{ } N=1.36 / \sqrt{ } 79)$ is given as

$$
D=\alpha / \sqrt{ } N=1.36 / \sqrt{ } 79=0.1530
$$

To this end, the calculated $D$ value $(-0.2616)$ is less than the critical value of 0.1530 , the null hypothesis $\left(\mathrm{H}_{0}\right)$ stating that electronic payment systems have not been fully accepted in the Nigerian insurance industry is accepted at $\alpha=0.05$ (see Table 4), this, therefore, implies that the alternate hypothesis that electronic payment systems have been fully 
accepted in the Nigerian insurance industry is rejected, with regards to the responses of the respondents.

\section{CONCLUSION}

This research attempts to examine the implementation of electronic payment systems in service delivery of insurance companies in Nigeria. While the study proves an improvement in electronic payment systems in relation to service delivery process within the Nigerian insurance market space, it was discovered that electronic payment have not been fully accepted within the Nigerian insurance industry. The study of Tennyson \& Mercy (2014) had noted reasons why electronic payment systems are significant to include: improvement of quality of life; improvement of effective service delivery and increase in the social well being of Nigerians; provision of quicker and better services and spontaneous responses to demand conditions; enhancement of competitiveness and helps to gain a competitive advantage.

Conclusively, the study establishes that greater investment in the technological capabilities of insurance companies will advance customer service delivery process. This is in consistent with recent studies, such as Aduloju, Olowokudejo, \& Obalola (2014), Idris et al. (2013), Breznik (2012), Chen \& Tsou (2007), and Ray, Muhanna, \& Barney (2005), among others]. For example, while the study of Ray et al. (2005) expressed that a firm may be placed a competitive disadvantage in terms of the performance of its customer service process if there is failure to invest in IT resources and capabilities; Idris et al. (2013) opined that customer service delivery process of insurance companies in Nigeria can become better if they invest more in information technology, make provision for IT training facilities to staff from time-to-time, and educate their customers to ensure faster, smooth and quality service delivery performance.

Recommendations, Research Implication and Suggestions for Future Studies

On recommendation, practitioners of insurance should gear up to meeting with the challenges posed by the implementation of electronic payment systems towards service delivery. More so, continuous investment in technology is imperatively crucial to allow for cordia business relationship among all players in the Nigerian insurance market environment. Greater attention therefore should be placed on customers' education and engagement in the use of electronic payment systems to enhance business transactions. Government initiative towards cashless policy should be made feasible by continuously encouraging members of the public towards transacting business electronically. Regulators are advised to push policy that will ensure implementation of and continuous improvement in the use of electronic payment systems in the Nigerian insurance market environment. Insurance companies should liaise with banks in the effective payment of premium via their Automated Teller Machine (ATM) and lastly, insurance companies should set up outlets whose business is to ensure the workability of Point of Sale (POS) Terminals in the collection of premium to ease customers in their payment procedure.

The implication of this study is that it helps educate insurance companies' managers of need to continually assess their firms' customer service performance with respect to IT-based facilities and the need to integrate their service delivery process alongside electronic systems. This study thus informs regulatory authorities of the need to design policy that will aid electronic payment systems implementation within Nigeria's insurance market space. This study serves as an eye-opener to major players within the Nigerian insurance industry, and lastly, contributes to knowledge in that it educates insurance practitioners of the dynamics of electronic payment systems.

This study suggests that future studies should focus efforts at gathering information from the insuring populace as related to electronic payment usage. Additionally, the various electronic payment modes should be understudied to ascertain their acceptance level among the insuring public. Research efforts could be drawn at designing electronic payment model that could best work for insurance companies in Nigeria. Lastly, future research could also attend to the effectiveness and efficiency of electronic payment systems within the Nigerian insurance industry.

\section{REFERENCES}

Aduloju, K., Olowokudejo, F., \& Obalola, M. (2014). Information technology and customer service performance among insurance companies in Nigeria. European Journal of Business and Management,6(20), 80-87.

Agboola, A.A. (2006). Electronic payment and Tele-banking services in Nigeria. Journal of Internet Banking and Commerce, 11(3). Retrieved from http://www.arraydev.com/commerce/jibc

Ajemunigbohun, S.S., Dansu, F.S., \&Asokere, S.S. (2010). Marketing: Repolishing insurance service delivery (Nigeria's Case). Proceeding of the Fourth African Regional Conference on Sustainable Development,4(13),15-18

Aldridge, A., \& Levine, K. (2001). Surveying the social world: principle and practice in survey research. Buckingham: Open University Press.

Asika, N. (2008). Research methodology in the behavioural sciences. Lagos: Longman Nigeria PLC

Asikhia, O. (2010). Customer orientation and firm performance among Nigerian small and medium scale business. International Journal of Marketing Studies, 2(1), 197-212.

Auta, E.M. (2010). E-banking in developing economic: empirical evidence from Nigeria. Journal of Applied Quantitative methods, 5(2), 212-222.

Ayo, C.K., \& Ukpeke, W.I. (2010). Design of a secure unified e-payment system in Nigeria: A case study. African Journal of Business Management, 4(9), 1753-1760.

Baddeley, M. (2004). Using e-cash in the new economy: An economic analysis of micropayment systems. Journal of Electronic Research, 5(7), 239-253.

Breznik, L. (2012). Can information technology be a source of competitive advantage? Economic and Business Review, 14(3), 251-269.

Chandio, F.H. (2011). Studying acceptance of online banking information system: A structural equation model. A thesis submitted for the degree of Doctor of Philosophy. Brunel University London: Brunel Business School.

Chen, J.S., \& Tsou, H.T. (2007). Information technology adoption for service innovation practices and competitive advantage: The case of financial firms. Information Research, 12(3), 314-336.

Cooper, D.R., \& Schindler, P.S. (2005). Business research methods (9thed.). New York: McGraw-Hill.

Davis, C. (2003, November). Cutting the cost of recurrent electronic insurance payments. US: Electronic Payment International.

Egan, J. (2004). Relationship marketing: Exploiting relational strategies in marketing (2nded.). Essex: Pearson Education Limited.

Ekwueme, C.M., Egbunike, P.A., \& Amara, D. (nd.). An empirical assessment of the operational efficiency of electronic banking: Evidence of Nigerian banks. Review of Public Administration and Management, 1(2), 108-137.

Fenuga, O. J., \& Oladejo, R.K. (2010). The effect of electronic payment on customer service delivery in Nigerian banks. International Journal of Economic Development Research and Investment,1(1), 227-239. 
Hewer, P., \& Howcroft, B. (1999). Consumers' distribution channe adoption and usage in the financial services industry: A review of existing approaches. Journal of Financial Services Marketing, 19(6), 222-231.

Howcroft, B., Hamilton, R., \& Hewer, P. (2002). Consumer attitude and the usage and adoption of home-based banking in the United Kingdom. The International Journal of Banking Marketing,20(3), 111-121

Humphrey, D.B., Kim, M.,\& Vale, B. (2001). Realizing the gains from electronic payments: cost, pricing, and payment choice. Journal of Money, credit and Banking, 33(2), 216-234.

Idris, A.A, Olumoko, T.A.,\& Ajemunigbohun, S.S. (2013). The role of information technology in customers' service delivery and firm performance: Evidence from Nigeria's insurance industry. International Journal of Marketing Studies, 5(4), 59-71.

Ikupolati, M. (2008). Principles and practice of insurance marketing - The PMI approach. Lagos: Nigerian Insurers Association.

Kaleem, A., \& Ahmad, S. (2008). Banker's perceptions of electronic banking in Pakistan. Journal of Internet Banking and Commerce, 13(1), 1-16.

Kiang, M.Y., Raghu, T.S., \& Hueu-Min, S.K. (2000). Marketing on the internet - who can benefit from an online marketing approach?.Decision Support Systems, 27(4), 383-393.

King, C. (1992, October). Agents/Policy owners split on service. National Underwriter, 41(7), 1-8.

Lee, Z.Y., Yu, H.C., \& Kuo, P. J. (nd.). An analysis and comparison of different types of electronic payment systems.

Lim, B., Lee, H., \& Kurning, S. (2007). Exploring the reasons for a failure of electronic payment systems: A case study of an Australian company. Journal of Research and Practice in Information Technology, 39(4), 231-243.

Lovelock, C., \& Wright, L. (1999). Principles of service marketing and management. New York: Upper Saddle River.

Min, H., \& Gallen, W.P. (1999). Electronic commerce usage in business-to-business purchasing. International Journal of Operation and Production Management, 19(9), 909-921.

Moses-Ashike, H. (2012, November). FCMB lists factors for successful implementation of e-payment. Wednesday, 21.

Nigerian Insurers Association (2013). Nigeria Insurance report.

Nnaka, P. (2009). The Nigeria e-payment system, Nigeria Monthly, 4(8), 25-27.

Nwankwo, S.I., \& Ajemunigbohun, S.S. (2013). Customer relationship management and customer retention: Empirical assessment from Nigeria's Insurance Industry. Business and Economics Journal,4(2),81.doi:10.417/2151-9219.1000081.

Nwankwo, S.I., \& Durowoju, S.T. (2011). Customers' evaluation of the quality of insurance services in Lagos, Nigeria. International Journal of Business and Management, 6(10), 265-272.

Oghojafor, B.E.A., Aduloju, S.A., \& Olowokudejo, F.F. (2011) Information technology and customer relationship management (CRM) in some selected insurance firms in Nigeria. Journal of Economic and International Finance, 3(7), 452-461.

Oladejo, M., \& Akanbi, T. (2012). Banker's perceptions of electronic banking in Nigeria: A review of post consolidation experience. Research Journal of Finance and Accounting, 3(2), 1-11.

Organization for Economic Co-operation and Developmen 2006, April). Online payment systems for e-commerce. Directorate for Science, Technology and Industry Committee for Information, Computer and Communications Policy, 18, 1-55.

Otisa, K.N. (2012). Effect of perceived ICT payment system on customer satisfaction at the Kenya power and lighting company. Journal of Emerging Trend in Economics and Management Science, 3(4), 398-402.

Pagano, P.R. (1994). Understanding statistics in the behavioural sciences (4thed.). USA: West Publishing Company.

Ray, G., Muhanna, W.A., \& Barney, J.B. (2005). Information technology and performance of the customer service process: A resource-based analysis. MIS Quarterly, 29(4), 625-652.

www.journals.cz
Stan, M. (1997, May). Telebanking: The thing in Britain. Weekend Concord, Saturday, 19.

Suganthi, B., \& Balachandran, P. (2001). Internet banking patronage: An empirical investigation of Malaysia. Journal of Internet Banking and Commerce. Retrieved from http://www.arraydebv.com/ commerce/jibc/0103 01.htm.

Sumanjeet, S. (2009). Emergence of payment systems in the age of electronic commerce: The state of art. Asia Pacific Journal of Finance and Banking Research, 3(3), 18-40.

Tahir, T., \& Abass, K. (2013). Assessment of risks involved in electronic payment systems. International Journal of Science and Research, 2(8), 406-412.

Taylor, S.A., Celuch, K., \& Goodwin, S. (2002). Technology readiness in the e-insurance industry: An exploratory investigation and development of an agent technology e-consumption model. Journal of Insurance Issues, 25(2), 142-165

Tennyson, O., \& Mercy, O.E. (2014). E-payment system and its sustainable development in the Nigerian economy. European Journal of Business and Management, 6(8), 48-56.

Thornton, J., \& White, L. (2001). Customer orientations and usage of financial distribution channels. Journal of Services Marketing, 15(3), 168-185.

Toran, D. (1993). Quality service (quality everything). LIMRA'S Market Facts, 12(3), 10-11

United States Agency International Development (2012). Standards and Practices reports for electronic and mobile payments. USA: Global Broadband and Innovation.

Walker, J., \&Baker, J. (2000). An exploratory study of multiexpectation framework for services. Journal of Service Marketing, 14(5),411-431.doi: 10.1108/08876040010340946.

Zulu, B. (2006). E-payment a challenge for Africa. Available athttp://breadait.blogspot.com/2006/03/e-payment-challenge-forafrica.html [Accessedin September, 2014] 